\title{
The Role of Language and its Analysis in James Joyce`s Dubliners within the Light of Cultural Materialism
}

\author{
Mojgan Gaeini ${ }^{1}$, Mahnaz Soqandi ${ }^{2}$, Fatemeh Sadat Basirizadeh ${ }^{3}$ \\ ${ }^{1}$ Islamic Azad University, Qom Branch, Qom, Iran \\ ${ }^{2}$ MA student in English Literature, English Language and literature Department, Faculty of Humanities, Semnan \\ University, Semnan, Iran \\ ${ }^{3}$ Young Researchers and Elite Club, Qom Branch, Islamic Azad University, Qom, Iran \\ 1mojgan.Gaeini@gmail.com,.3nbasiri2002@yahoo.com
}

\begin{abstract}
Language, Social identity and Religion are three major concerns of cultural studies. Language in literary texts plays a major role in constructing meaning and reflecting the author's intention. Likewise religion as a cultural politics is a dominant factor in shaping mind as well in affecting the framework of literary text. Religion is one of the emerging issues in the modern era and forms the backbone of most literary works. Religion as a theme is seen to influence the operation of those who believe in it. It forms the functional framework that predetermines ones actions and behavior. Furthermore, social identity decides on the status of the social class and their material life situation. Social identity relates to how we identify ourselves in relation to others according to what we have in common. All these issues are interrelated since they all cooperate and construct a social and cultural materiality. James Joyce could be placed among the most dominant cultural authors whose concern is the material life, social class, social identity and cultural crisis. As an outstanding author, Joyce is well known for his typical depiction, musical decoration as well as his sticking to proper cultural and social materials and issues such as religious matters. His major short story collection, Dubliners, revolves around the lifestyle of the Irish middle-class in Dublin around the late 1800s and early 1900s. This collection is decorated with violated norms and ritualistic behavior that are part of social constructs. Addressing social, religious and cultural issues, cultural materialists believe that "literature can serve as an agent of change", since a culture's hegemony is unstable. Raymond Williams views culture as a "productive process" that is, part of the means of production, and cultural materialism often identifies what he called "residual", "emergent" and "oppositional" cultural elements. Seemingly, James Joyce`s Dubliners pertains to the notion of language, social identity and religion as cultural practices within the framework of cultural materialism. This study aims to clarify how James Joyce`s Dubliners reflects the notions of language, social identity and religion as cultural practices and how they construct social and cultural products within the framework of cultural materialism to show how James Joyce criticizes Irish culture at the beginning of the Twentieth century.
\end{abstract}

Keywords : Cultural Materialism, Social Identity, language; religion; infrastructure

\section{Introduction}

This paper explores Raymond William analysis of cultural materialism and power of language in James Joyce 's Dubliners within the framework of Cultural Materialism. Raymond Williams is one of the most important and influential cultural theorists. The core of this chapter is to examine the language in the following short stories: An Encounter, The Boarding House, A Painful Case, A Mother, The Dead, The sisters, Araby and Grace. Language plays a vital role in bringing out the theme throughout the novel. This chapter shows light on the ins and outs of the novel from a cultural materialistic point of view and 
discusses the use of language as the symbol of power. In the light of an illuminating comment made by Seamus Deane in The Cambridge Companion to James Joyce:

The speaker of Irish-English in the world of increasingly Standard English finds it too difficult to conform to the imperial way. He takes as his script the advice: "When in Rome, do as the Greeks do." There is a certain scandal in such behavior. It is a linguistic way of subverting a political conquest (1).

James Joyce is not so much a writer as he is a painter of words. His works appear simplistic at first glance, but under analysis they reveal the inner world of a character and the reality of the common man through symbols, metaphors, and sensory analysis. Dublin is the city of silence which threads its way through the lives of the Dubliners, for this reason Joyce's characters are presented in a silent state. Such silence denotes the sterility of communication and the absence of the art of conversation. Most of Dubliners characters are portrayed as having the ability of verbal activity and they can speak, yet in most cases this ability fails them and they become tongue-tied.The only way which is left for them is speak in a whispering voice. In the modern age, life has completely changed and the city has become a modernized one. This latter is the epitome of such change that has a great effect upon the modern life, bringing with it the trauma and frustration of modern failure. In this way, by the turn of the century Northern Ireland has become an arena of stillness and stagnation .Due to many factors such as the English pressure and the atrocities of the modern era great changes have altered the stream of Irish society, leading to spiritual void as well as social paralysis. Dubliners tackles the glaring sunbeams of that era and tries to denote and portrays the soul of that city, chronicling the decay of its morals and of its spiritual life by focusing on emotional paralysis of its inhabitants. (Taglieri, 7).

\section{Review of Literature}

Raymond Henry Williams coined the term Cultural materialism. He was welsh academic, novelist and critic. He was an influential figure within the new left and in wider culture. His writings on publics, culture, the mass media and literature are a significant contribution to the Marxist critique of cultural and arts. (Williams, 1977) 'Empirical' work quite systematically transgressed the boundaries between elite and popular cultures. He was an interested in television and the press as a canonical literature and drama. Hence, his insistence that concepts both 'literature' and 'criticism' were forms of a class specialization and control of a general social practice, and of a class limitation of the question" (Williams, 1977). (Harris, 1927) pointed out that the cultural materialism is the strategy has found to be most effective in his effort to understand the causes of differences and similarities among societies and cultures. It is based on the simple premise that human social life is a response to the practical problems of earthly existence. Alan Sinfield, Cathering Belsey and Jonathan Dollimore are showing in their works the theory of Cultural Materialism. Their approach has been distinguished from the somewhat similar school of New Historicism in that they hold a less pessimistic view of the prospects of cultural dissidence and resistance to established powers. In view of the fact that literature performs an energetic role among the thought yet consolidation about power, a literary textual content does not in basic terms reveal the culture in which it is produced, however additionally actively contributes in conformity with the constitution of that culture. Cultural materialism tries according to convey in conformity with 
light how ideology then as a result existing social order tries in conformity with preserve itself through literature without losing its grip.

The Cultural materialist has some kind of idealistic motives, like as pure, unselfish devotion to humankind, rightly or wrongly, a large segment of world opinion. The Anthropological thinkers Marx has given right responsible for all the people. Likewise Joyce demonstrated in Dubliners, materialist as an elite people. They were ruling like a cruel and dominated to other. perception of the dominant culture is never the only one in the cultural field, although it is the most powerful, there are always residual and emergent strains within a culture that offer alternatives to hegemony. In other words, the dominant culture is always under pressure from alternative views and beliefs. The people dominating to other; they were losing all these ruling system one day. The people are not given response to them. It was happened in the global world. Now-a-days everyone has followed the government rules. Sometimes, it is changed occasionally. The materialist exploited some strategy and given right responsibility for all. Every part or group of people is called as a materialist.

The dominant cultural materialist is always under pressure, striving to substantiate their claim to superior explanatory power in situations where diverse features are resistant. William's argument that culture has always to be produced: 'social orders and cultural orders must be seen as being actively made: actively and continuously, or they may quite quickly break down' (William 1997, 201). (Howard, 1992) argues that the image of culture is the past resonates powerfully with 'some of the dominant elements of postmodern culture'. From this point of view, cultural materialism re-enacts new historicism's tendency to 'see an image of the seeing self' in its objects and representations. (Young, 1988) suggests that this structure of reflection is crucial to cultural materialism since it enables its proponents to argue the contemporary relevance of their historical findings. Communication is forbidden, and language has become the tool of the oppressor, as (Gussow, 1994) has proved that Joyce 's novel is about suppression of language and the loss of freedom of expression feel. Raymond Williams presents his own orientation to language thus:

We can also come to see that a sign-system is itself a specific structure of social relationships: "internally," in that the signs depend on, were formed in, relationships; "externally," in that the system depends on, is formed in, the institutions which activate it (and which are then at once cultural and social and economic institutions); integrally, in that a "sign-system," properly under stood, is at once a specific cultural technology and a specific form of practical consciousness: those apparently diverse elements which are in fact unified in the material social process. (Williams 1977, 140)

Language is only one of those practices implicated in the symptoms of the crisis of late capitalist society. Faced with the ideological mystification of personal lives, Williams stressed the imperative of establishing connections by emphasizing the role of means of communication (he speaks of "productive communication") in shaping community. He opposed the mechanical formulas of "vulgar Marxism" (this version reduced culture to a simple reflection of commodity-production-for-profit) and the positivist axioms of structuralfunctiontionalism by a radical historicizing of contexts and collectivities. This did not imply a retreat to a vitalist, romantic nihilism, or a privileging of anarchic will, ambiguous and hybridized positionality, or organic Volkgemeinschaft. Williams's reconstruction of historical materialism eludes such "Commonsensical" reflexes. Williams returns us to the ineluctable pressures and limits of history, of the body and physical nature, in order to calculate determination, the measure of necessity. This illuminates also the differences between the 
hegemonic and subaltern classes. He does so not to revive mechanical determinism or arbitrary closure but, on the contrary, to recover the principle of intention. He was himself intent on carrying out a cognitive mapping of social agency and direction sedimented in specific traditions and various formations, discover able through "structures of feeling" and "knowable communities," from a European and later global perspective.

For Williams, the introduction of Gramsci's theory of hegemony and the role of intellectuals in cultural formations advanced and deepened the reach of cultural theory. Culture now becomes the site of power antagonisms and differential lines of force. It is at this junction that Williams resumes the actual genealogy of cultural studies from the debate over the "changing and contested structure of public education" and the influence of the new media (television, film) that has drastically revised "all received definitions of majority or popular cultural enterprise." The influence of Saussure, Freud, and others who valorized the text and the language-paradigm above all strikes Williams as dam aging in that it negated the paramount task of an all-sided cultural analysis, namely, "the identification of the matrix of any formation," "the analysis of specific relationships through which works are made and move." Cultural studies examine the socially and historically specifiable agency of the work's making, "an agency that has to include both content and intention, in relative degrees of determinacy, yet is only fully available as agency in both its internal (textual) and social and historical (in the full sense, formal) specificities" (Williams, 172).

Joyce explores the levels of the modern self, not giving the reader a clear identity to his characters. This results in the effect of the characters not possessing their own voice or language. This inability to express one's self has been discussed before in terms of Dubliners' characters and should be brought into this discussion as well. According to Trevor L. Williams in his article, "Resistance to Paralysis", there seems to be a "frequent tendency" in Dubliners for characters "not to be in control of language" and for these "characters simply to [not] possess a language" (438). Joyce allowed the devastating effects of colonialism in Ireland to seep through his gaps, which is indeed noticeable in the creative third space he invents in Dubliners. In all of the fifteen stories one finds these deafening silences and gaps, exposing the reader to the character's inability for progress and change from their current life situations for the better.

In the story "A Mother", the aspiring character of Mrs Kearney wishes nothing more than to be part of Dublin's high society. Her desire of becoming one of the elite is pressured onto Kathleen by forcing her daughter to take center stage at a respected play. However, all does not go according to plan and, ultimately, her inability to correctly use the language and social conduct of the higher classes' snuffs out her dreams entirely. In Trevor L Williams' article, "Resistance to Paralysis in Dubliners", he points out Mrs Kearney's attention to the "language and pronunciation" of those around her (445). This can be in part due to her refined upbringing. In the following excerpt taken from Dubliners, the narrative voice presents us with a summary of Mrs Kearney's past:

She had been educated in a high-class convent where she had learned French and music. As she was naturally pale and unbending in manner she made few friends at school. When she came to the age of marriage she was sent out to many houses where her playing and ivory manners were much admired. She sat amid the chilly circle of her accomplishments, waiting for some suitor to brave it and offer her a brilliant life. (116) 
What is strange with Mrs Kearney is that, although brought up in a very affluent environment, she does not seem to understand the code of conduct of the culturally distinguished higher classes. She is quick to notice the accents of those around her such as that of the secretary of the Society, Mr Fitzpatrick. His "flat accent" and the way he "carelessly" wore his "soft brown hat" were all too noticeable to her (119). It is apparent in the way she notices his unsophisticated accent and his proletariat way of wearing his hat that social refinement is important to her. A recurrent motive in Dubliners is that of dispossession which is expressed here in the character's lacking rhetorical control when it comes to the language of cultural distinction. One can begin with considering Mrs Kearney's obsession with manners and correct grammar and pronunciation. She picks up on the improper usage of "yous" by Mr Duggan and of how he "carelessly" wiped his nose with his gloved white hands (122). It shows lack of self-control.

In the story Grace, During Joyce's lifetime, Catholicism was the religion fervently exercised by a majority in Ireland. Trevor L. Williams describes the characters as not being able to "define what Catholicism is" (448). Most fervent worshippers, however, had a vague idea of what it was meant to be Catholic. Trevor L Williams' argument that characters have trouble "controlling language" and who are in turn "controlled by the language they speak" (448).

In the story, Irish culture mingles with the English language of the oppressor. There instances where the narrative reveals this. In the first instance, we find an allusion to England in the form of Protestant Mr Kernan. The friends who are trying to return him wholeheartedly to Catholicism can be read as a reference to Ireland, as the narrator describes in the following passage:

$\mathrm{He}$ was quite unconscious that he was the victim of a plot which his friends $\mathrm{Mr}$ Cunningham, Mr M'Coy and Mr Power had disclosed to Mrs Kernan in the parlour. The idea had been Mr Power's but its development was entrusted to Mr Cunningham. Mr Kernan came of Protestant stock and, though he had been converted to the Catholic faith at the time of his marriage, he had not been in the pale of the Church for twenty years [...] Mr Cunningham was the very man for such a case. (134)

This excerpt suggests the ever- present, religious battleground between Protestant England and Catholic Ireland. Mr Kernan having fallen to the bad ways of drinking needs to be "saved" by the Catholic Church, especially since he comes from a Protestant background. The confusion of the story's language reveals the artificiality of these distinctions between the cultural and religious sensibilities between the two countries. What the characters do not own is a language of social cohesion and solidarity, as they are divided along the lines of gender, religion, class, and ethnicity.

In another instance of language power, we are presented to Mr M'Coy, the language authoritarian. He interrupts Mr Kernan's speech when either he cannot find the word he wants to use or when Mr M'Coy wishes to show dominance in the English language. In the following excerpt, we see a clear example of this:

- No, said Mr Kernan. I think I caught a cold on the car. There's something keeps coming into my throat, phlegm or...

- Mucus, said Mr M'Coy.

- It keeps coming like from down my throat; sickening thing.

- Yes, yes, said Mr M'Coy, that's the thorax. 
He looked at Mr Cunningham and Mr Power at the same time with an air of challenge. (136)

By using more advanced words, Mr M'Coy exposes the reader to Mr Kernan's "linguistic poverty" as coined by Trevor L. Williams (448). Since Mr Kernan does not understand the English language well, he cannot own it. Of course the Irish can use English as well as an Englishman can, however, Joyce wants the Irish reader to understand that English is not their own language and that they need to find their own in order to spur on Ireland's cultural growth.

In the last two examples, the theme is that of not owning the religious language. When the men who have come over to the Kernan's try and convince Mr Kernan of the validity of the Catholic Church, he is finally convinced because of two things: The respect he has for Mr Cunningham as being a learned man and because of his belief that the Jesuit order is an educated lot. This is revealed in the following dialogue:

- I haven't such a bad opinion of the Jesuits, he said [...] they're and educated order. I believe they mean well too. [...]

- They're all good men, said Mr Cunningham [...] The Irish priesthood is honored all the world over $[\ldots]$

- Perhaps you're right, said Mr Kernan relenting [...] Mr Kernan [...] was impressed.

- He had a high opinion of Mr Cunningham as a judge of character and as a reader of faces. (141-42)

Another example of his inability to understand religion through language is given in the following excerpt where they discuss the scholarly greatness of Pope Leo:

-Pope Leo, you know, was a great scholar and a poet.

- He had a strong face, said Mr Kernan.

-Yes, said Mr Cunningham. He wrote Latin poetry. (144)

The process of identification here begins with Mr Kernan as an incurable drunk who is slowly but surely "saved" by the religious persuasions of his Catholic friends. Since he is ignorant in the teachings of the Catholic faith, he puts his trust in those who seem respectable or knowledgeable enough and ends up being persuaded blindly into accepting the Catholic faith over his Protestant one. His process of identification ultimately leads him into failure due to his own confusion about faith and language.

\section{Discussion}

\subsection{The Role of Language and its analysis in The Sisters}

"The Sisters", the opening story, seems to perform an expository role for the whole by using three complex words which are 'Paralysis', 'Gnomon' and 'Simony'. The narrator, presumably a child, utters these words without comprehending their deep import. However, his application of the word 'paralysis' to Father Flynn does not surprise us much, but when he calls the dead priest 'simoniac', his precocity startles us for the apt use of the word to the mysterious life led by the Father.

From the beginning when Nannie suggestions the crackers to the boy, he refuses eating them since he is thinking that he would make too much noise eating them (4) as a whole mask of silence camps down every now and then. In the Dead, there is sickness in conversation as when one of the character speaks, the listener does not care of what the 
speaker is saying. For example in the Morkans party, when Mr.Browne is speaking and he did not finish his sentence, but, seeing that Aunt Kate was out of earshot (Joyce 115).Later on in when the couple is in the hotel room Gabriel does not find proper words to start a conversation with his wife, though they are married for so long and they have children. The husband cannot ask his wife directly and after hesitation and thinking twice the male decides to speak with Gretta.

"By the way, Gretta!"

"What is it?"

"You know that poor fellow Malins?" he said quickly (Joyce 138).

In The Sisters, the unnamed boy in the bed sees a spirit which is willing to confess something, yet it confess to me in a murmuring voice (Joyce 2) but he fails to decode what it is saying as the spirit cannot utter correctly because of the spiritual paralysis. The Irish society is "weakened by centuries of useless struggle and broken treaties where individual initiative is paralyzed" (Taglieri, 7) and the whole rain of problems pelts heavily on the individuals.

Furthermore, in The Sisters because there is nothing common between the guests and the hosts a total silence took possession of the little room in which no one is able to kindle up a thread of conversation. The guests waited respectfully for her to break the silence and the boy also too listened; but there was no sound in the house. As they are there but not really there, since their bodies are on land but their souls are roaming elsewhere, trying to find a suitable place. Though Gabriel is an eloquent university teacher, he is unable to defend himself before Miss Ivors .He instead murmured lamely that he saw nothing political in writing reviews of books (Joyce 119).

An interesting and specialist literary critic of Joyce's Dubliners is Gottlieb Gaison, whose work entitled International Perspectives on James Joyce (1986), dealt with the way Joyce had presented the female characters throughout Dubliners. In it, the critic described the role attributed to the female characters and how Joyce's women in general were torn between two worlds, the patriarchal and the colonial worlds. According to the critic analysis, Joyce had presented Dublin as a society dominated by the authoritarian powers established by men. Thus, he wrote Dubliners is oddly a sterile and womanless. Joyce depicts a desiccated Garden of Eden inhibited by a fallen race whose maternal center has been erased" (Gaison, 16). He further stated that women in the sector life of the patriarchal Dublin were given no voice, they were voiceless. Within this context, he said that:

They (women) attempt to speak, their words are reduced to vacuous gibberish. Deprived of power and logocentric control, they cannot master the language of the dominant society, and they function as servants to the cultural imperatives that circumscribe their lives.(134)

The characters in Joyce's stories are held fast by the "paralyzing" effect of Dublin city life, subjugated by the ideologies of church and state: "Work is drudgery, politics a farce, religion either empty ritual or a form of madness, and domestic life a prison... Shame, guilt, rage, violence and humiliation simmer beneath the threadbare surfaces of social life." ((Eagletone, 298). Eagleton describes "scrupulous meanness" as a kind of "neutral realism" which reflects the stagnation and sparseness of the characters' lives. Joyce's style is "a deliberately flattened, economical style which captures what he saw as the "spiritual paralysis of his city and his country." (Eagleton, 299). 
In a sense, the domineering's language has become the dominant medium of communication. Joyce's novel may be peppered with Irish idioms and idiosyncrasies, and his subjects may be intensely Irish the Catholic Church, Irish politics, myths and superstitions but the only language at his disposal is that of the colonizer. English. And it is the historical moment of Joyce's work, a time when the Irish republican movement was growing in strength prior to the 1916 Easter Rising, which gives it a political dimension.

Language in Ireland had always been a political and cultural minefield, as the tongue of the colonialist vied with the despised discourse of the natives. In a nation where you could move between several kinds of speech (Irish, English, Hiberno-English, Ulster Scots and so on), writers were more likely to be aware of the problematic nature of language than those who, like the English, could take their so-called mother tongue for granted. Language in such situations is less a transparent medium than an object of concern and contention in its own right. And this aligns it with modernism rather than with realism. (Eagleton, 287)

The hero of this story, "The Sisters," is a young boy whose men tor, a paralyzed priest, has died. This is an important moment for the boy, and he is highly receptive, listening and thinking, searching for understanding of his own emotions about the priest and his death, and beyond that, an understanding of the religion, the world view, and the priest represents and teaches. But there is something "off" about the priest: it seems he is (to mix religions) not quite kosher. The boy listens first, disguising his intentness, to an old man and his uncle talking about the priest. He then moves into himself, his emotions, sensations, a dream. In the final segment of the story, he attends the priest's wake, seeing the dead body, and listening to the conversation of two old women (the priest's sisters) and his aunt. In the course of the story, he is exposed to the old and the middle-aged of both genders; the old people and the aunt and uncle represent, indeed are, the passers-on of culture, tradition, and knowledge. Yet the boy learns very little from them, and what he learns is elliptical and euphemistic, is fraught with a heavy and ominous weight of the unspoken. The boy (and the reader) ends confused, disturbed, and suspicious. The form of the story forces the reader to experience what the boy experiences, no authorial help is offered. Because the "truth" has been concealed by masking language, the boy ends with no understanding of his feelings and no understanding of the priest, whether as human or as representative. What is conferred on him by the entire event is an intimation of a reality too evil to be uttered, and a set of associations (religion/sex/power/sin) that he will carry with him thenceforth. The actuality of the situation, which might well have been fairly simple and understandable, has been turned by masking language into a terrible and enigmatic question. Thus, masking language not only conceals the real, but creates a different reality. Like genuine language, it ex presses a traditional "what is," but at the same time, it creates a new "what is," and perpetuates both.

The effect of such training in language is traced in grim detail throughout the rest of Dubliners. Its characters are drawn mainly from the lower economic classes, those with little education and ability to penetrate the falsehoods of cultural configurations. Linguistic and logical ellipses, cliché of thought and attitude, continue to plague and eventually paralyze the characters, who cannot act on a reality they do not even see. However, in the course of writing these stories, Joyce began to see that insincerity is not necessarily conscious. Insincerity is attitudinizing, adopting a particular posture for a particular purpose. This purpose may be to deceive others, but the conscious hypocrite is a rare bird indeed in the work of James Joyce. His hypocrites suffer from a far more profound disease: they deceive themselves unwittingly. Their insincerity is the adopting of a cliché posture they have been taught to believe is correct, proper, and moral. So effective has their teaching been that they 
are not aware, or only vaguely aware, that their actual feelings and thoughts do not coincide with the words they are uttering, the gestures they make.

\subsection{The Role of Language and its analysis in The Dead}

The Dead is not only concerned with human death but with the death of language itself. One of the clues is in the very first line of the story: "Lily, the caretaker's daughter, was literally run off her feet." (Dubliners, 127) A closer examination of the sentence will reveal that it does not actually make any sense. If Lily was merely "run off her feet" we would interpret this in the figurative sense that she was running around very busily. But Joyce makes a mockery of the metaphor by the use of the word "literally", which would normally mean factually rather that figuratively. In this sense he not only draws attention to the precariousness of language from the very beginning, he also initiates a kind of "deconstruction" of the text which has thematic potency for the rest of the story: "[...] the opening sentence to the story produces a play of figuration which refers indirectly both to the subject of the story, death, and to its telling [...] The Dead, which is above all about death, is also about dead language, dead metaphors." (Bennett \& Royle, 86)

In the story "The Dead" (which is in many ways a comment on and corrective to the stories which precede it), is penetration to a reality which is broader and more profound than Gabriel's previous per sonal and self-centered vision. Cliché of language and thought fall away before Gabriel's recognition of general human blindness and isolation, and human kinship in the oblivion of death. The somber conclusion of this story, and the volume represents both a rein forcemeat of the norms underlying the earlier stories, and a stretching of them.

Gabriel's penetration of the preconceptions of his society, and of his own selfbounded notions, represents a step towards wisdom and humaneness: it is an unquestioned good, although it brings pain. But his recognition that blindness is a general condition, and that what humans attempt to conceal from themselves and others is general isolation and the knowledge of mortality represents a stretching of the absolutism implicit in the earlier stories.

Joyce had concentrated on masking language as it appeared in pocket after pocket of his culture. By 1905, he had lived outside Ireland, and had probably found the "Irish" disease pandemic. It is understandable that he might mollify his judgment of individuals who use masking language, and shift his gaze inward in an attempt to discover why such use occurs.

\section{Conclusion}

To conclude Dubliners is a novel of Joyce that deals with cultural materialistic approach among Irish people. It lends itself to a Raymond Williams analysis of cultural materialism and symbol of power. The symbol of power meant that superior religion, politics. the concept of the language power is discussed in the selected stories of Dubliners What is created is an imaginary space where the migrant writer's conception of Ireland as a culturally divided space understood from the perspective of a migrant reveals itself through the language of the narrative. The Irishness of the characters emerges through this space, allowing the reader to follow their process of identification. What the characters demonstrate in their processes of identification is an inability to own their own language. This inability is presented either in the form of not owning their own voice, not owning the language of cultural distinction or of having social cohesion and solidarity. It is a story of Joyce's Ireland, 
portrayed in a light of total cultural desolation after years of colonial oppression. A portrayal of his native country, imaginatively constructed to awaken Ireland out of its cultural hibernation in the hopes of a new dawn of progressive cultural growth to form structures as a critical tool. Language is partly affected by a character's thought, as is often the case with Joyce's fiction.

\section{References}

Abrams, M. H. A Glossary of Literary Terms. New York: Harcourt Brace Pub, 1993. Barker, Chris. Cultural Studies: Theory and Practice. London: Sage publication Inc, 2004.

Barler, Chris. Sage Dictionary of Cultural Studies. London: Sage Pub Inc, 2003.

Bei, Xu. On Reproducing Literary Style of Dubliners in Chinese, a Thesis, Shanghai International Studies University, November, 2008.

Bulson, Eric. The Cambridge Introduction to James Joyce. Cambridge: Cambridge Press, 2006.

C. E. Bressler. Literary Criticism: An Introduction to Theory and Practice. The USA: PearsonPrentice Hall, 2007.

Claire, Kilroy. An Introduction to today's Irish Novelists. Dublin: Ireland Literature Exchange, 2010.

Daronkolahee, Esmaeel Najar. James Joyce's Usage of Diction in Representation of Irish Society in Dubliners: the Analysis of "The Sisters" and "The Dead" in Historical Context, The Journal of International Social Research Volume: 5 Issue: 23, Fall 2012. PP. 169-174.

DeVault, Christopher M., Love and Socialism in Joyce's "A Painful Case": A Buberian Reading, TCD library electronicdatabase, 2013.

Fargnoli, Nicholas A. and Gillespie, Michael P., Critical Companion to James Joyce: A Literary Reference to His Life andWork, Infobase Publishing, New York 2006.

Freese, Lee and Burke, Peter J. Persons, Identities, and Social Interaction, Department of Sociology, Washington State University. Advances in Group Processes, Vol.11. Greenwich, Conn.: JAI Press.

Greenblatt, Stephen. Culture in Critical Terms for Literary Studies. London: Faber and Faber, 2012

Harris, Marvin. Cultural Materialism: the Struggle for a Science of Culture, Walnut Creek, California: AltaMira Press, 2001.

(https://www.google.com/search?q=Harris,+Marvin.+Cultural+Materialism)

Hamlin, Madeleine. Geographies of Mobility in James Joyce'sDubliners, Literary Geographies, Vol.2, No. 2, Syracuse University, 2016. PP. 128-143.

Harris, Marvin. The Rise of Anthropological Theory: A History of Theories of Culture, Walnut Creek, California: Alta Mira Press, 2001.

Howard, J. The new historicism in renaissance studies, in new historicism and renaissance drama, eds. Richard Dutton and Richard Wilson. London: Longman, 1992.

Joyce, James. Dubliners: Authoritative Text, Contexts, Criticism. Ed. Margot Norris. New York: W.W. Norton, 2006.

J. Giles and T. Middleton. Studying Culture: A Practical Introduction. The USA: Wiley, 2008. 
Kearney, Martin F., Robert Emmet's Rising of 1803 and the Bold Mrs. Kearney: James Joyce's 'A Mother' as Historical.London.1981.

Kiberd, Declan. Inventing Ireland. London: Random House, 1995. Print.

Inglis, Tom.Local .Belonging, Identities and Sense of Place in Contemporary Ireland, in the Discussion Series: Politics and Identity No. 4, Institute for British-Irish Studies University, College Dublin, 2005.

Kuznar, Lawrence A. and Sanderson, Stephen K. "Marvin Harris's CulturalMaterialism and Its Legacy", Boulder, London: Paradigm Publishers, 2007.

Lozowski, Przemyslaw and Jarosz, Izabela. In Search of Cultural and Personal Experience behind woman in James Joyce's Dubliner, Artes Humanae, Vol. 1, 2016. PP. 157-174.

Milner, Andrew. Re-imagining Cultural Studies: The Promise of Cultural Materialism, London: SAGE Publications Ltd, 2002.

Moore, Jerry D. Marvin Harris. Cultural Materialism, Visions of Culture: An Introduction to Anthropological Theories and Theorists (2nd ed.), Walnut Creek, CA: AltaMira Press, 2004. pp. 203-215.

M. J. Smith. Culture: Reinventing the Social Sciences. Philadelphia: Open University Press, 2000.

Nazarieh, Mehrdad. James Joyce Dubliners: How Religion Influences Conscience, The Clarion: International Multidisciplinary Journal, Volume 5, 2016. PP 102-106.

Norris, M. Suspicious Reading of Joyce's Dubliners. Philadelphia: University of Pensylvania Press, 2003

Pereira, Vijay and Malik, Ashish. The Identities of Emerging and Developed Multinational Corporations and their effect on business and society, Journal of Race, Culture and Identity. Australia.

Prendergast, Christopher. Cultural Materialism: On Raymond Williams, Volume 9. London, Minneapolis: University of Minnesota Press, 1995.

Roughley, Alan. James Joyce And Critical Theory: An Introduction. Ann Arbor: University of Michigan, 1991.

Shrum, L. J., et al., Reconceptualizing materialism as identity goal pursuits: Functions, processes, and consequences, Journal of Business Research, 2012.

Suzuki, Talashi, Epiphanies in Dubliners, P 75-81.

Taglieri, Gina. 1996. James Joyce's Dubliners. United States of America: University of New York

Ward, Todd. A. Raymond Eastman, \& Chris Ninness, An Experimental Analysis of Cultural Materialism: The Effects of Various Modes of Production on Resource Sharing Behavior and Social Issues, 18, 2009. PP. 58-80.

Williams, R. Marxism and literature. New York: Oxford University Press, 1977.

Williams, Trevor L. Resistance to Paralysis in Dubliners, MFS Modern Fiction Studies Project MUSE. Web. 05 Mar. 2013. 